\title{
Postcolonial-Feminist elements in E. M. Forster's A Passage to India
}

\author{
Sarah Tavassoli \\ Semnan University, Iran \\ Narges Mirzapour \\ Semnan University, İran
}

\section{Introduction:}

Since postcolonial studies took the academic world by storm in the late 1980s, it has proven to be one of the most diverse and contentious fields in literary and cultural studies, a field of apparently endless argument and debate. Postcolonial literature and theory investigate what happens when two cultures clash and when one of them empowers and deems itself superior to the other. This theory moves beyond the bounds of literary studies and investigates the social, political, and economic concerns of the colonized and the colonizer. It highlights the various strategies adopted by colonized nations to resist this domination, and to decolonize their own lands and minds. In his essay, "The postcolonial and the postmodern: the question of Agency", in The location of Culture, Homi K. Bhabha asserts "postcolonial perspectives emerge from the colonial testimony of third world countries and the discourses of minorities within the geopolitical division of East and West, North and South" (171).

In the postcolonial phase, the status of women continues to preoccupy many critics. Under the current circumstances of globalization and almost complete sway toward a capitalitalist world-view, the condition of women has become a more urgent issue than ever. Until recently, feminist and postcolonial theory followed what Bill Ashcroft et al. call 'a path of convergent evolution' (Ashcroft et al. 249). Therefore, Feminism becomes a point of the interest of postcolonial discourse due to the fact that both patriarchy and imperialism exert analogous forms of domination over those rendered subordinates, i.e. women and colonized, respectively. Consequently, the policies of post colonialism and feminism oppose this kind of domination. As Neil Lazarus asserts, "feminist theory and postcolonial 
theory are occupied with similar question of representation, voice, marginalization, and the relation between politics and literature" (201). Both fields have emerged in response to the absence or unavailability of the perspectives of women, racial minorities, and marginalized cultures or communities in historical accounts and literary annals."Feminist and post-colonial discourses", Bill Ashcroft et al. argue, "both seek to reinstate the marginalized in the face of the dominant, and early feminist theory, like early nationalist post-colonial criticism, was concerned with inverting the structures of domination, substituting, for instance, a female tradition or traditions for a male-dominated canon"( 249).

However, in many circumstances, feminist perspectives are blind to the issues that relate to post colonialism and the international division of labor. Postcolonial studies also fail to include gender in their analysis. So, categories like gender are sometimes ignored within the larger formation of colonial, and postcolonial theory, which tend to cross out gender differences in constructing a single category of the colonized. Postcolonial feminism, as a dynamic and discursive field, supplements premises of both post colonialism and feminism with its own particular concerns and perspectives, and it is subject to criticism and revision by those premises. This approach tries to identify and rethink discourses built around the silencing, marginalization, and oppression of third-world women.

Postcolonial feminism, also dubbed third-world feminism, contends that thirdworld women are subjected to both colonial domination of empire and male dominance patriarchy. It is an investigation of and at the intersections of colonialism and neocolonialism with gender, nation, class, race, and sexualities in the different contexts of women's lives, their subjectivities, work, sexuality, and rights. In this approach, the emphasis is on the collusion of patriarchy and colonialism. However, it is a question of gender, in relation to race and class in the context of global population, articulated in postcolonial feminism. The major postcolonial feminism works move around themes such as monitory and combative addresses to First World feminists, the repudiation of the roles and places routinely assigned to women and feminists of the Third World, the formation of alliances, and the introduction of nuance and complexity into the politics of feminism.

In the 1980s, many feminist critics began to argue that Western feminism's assumption that gender overrode cultural differences to create a universal category of the feminine, was in fact operating from hidden, universalist assumptions with a middle-class, Euro-centric bias. As a result of their Eurocentric views, Western feminism fails to apply feminist theories to the historical, political, and sociocultural specification of black or third-world women. Writing in 1984, bell hooks bemoaned the fact that "white woman who dominate feminist discourse today 
rarely question whether or not their perspective on women's reality is true to the lived experiences of women as a collective group"(3). They in fact want to resignify the attributes of third world women that were imposed by western feminists on them. Katherine Mayo asserts that "It would be an evil day for India if Indian women indiscriminately copy and imitate Western women.Our women will progress in their own way... We are by no means prepared to think that the Western woman of today is a model to be copied. What has often been termed in the West as the emancipation of women is only a glorified name for the disintegration of the family" (95-96).

Chandra TalpadeMohanty's paradigmatic and influential essay, 'Under Western Eyes: Feminist Scholarship and Colonial Discourses', has frequently been acknowledged as a significant postcolonial challenge to mainstream Western feminism. First published in 1982, the essay is foundational in critiquing Western feminisms, which too easily elide the specific cultural difference and 'naturalise' all women's oppression under widely differing manifestations of patriarchal domination into European models. Mohantyasserts that "it is in this process of homogenization and systematization of the oppression of women in the third world that power is exercised in much of recent Western feminist discourse, and this power needs to be defined and named...."(260). Regarding the matter of representation, Western feminist scholars hold that the third world women cannot represent themselves and must be represented. Opposed to this idea, Mohanty argues that the representation of the average third-world woman as 'ignorant, poor, uneducated, tradition-bound, domesticated, family-oriented, victimized', facilitates and privileges the self-representation of Western women 'as educated, modern, as having control over their own bodies and "sexualities", and the "freedom" to make their own decisions' (261).

Another influential critic in this field is GayatriChakravortySpivak, whose focus is mostly on cultural differences between women in the 'Third World' and women in the 'First World'.Spivak'srearticulation of subaltern women's histories in her famous essay, 'Can the Subaltern Speak?', also radically transformed the terms and focus of Western feminist thought. In this essay, Spivak famously elaborates some other contexts wherein contesting the representational systems, which violently displace or silence the figure of the 'gendered subaltern'. As she writes: "Between patriarchy and imperialism, subject-constitution and object-formation, the figure of the woman disappears, not into a pristine nothingness, but a violent shuttling which is the displaced figuration of the 'third-world woman' caught between tradition and modernization". ${ }^{1}$ Spivak thus cautions against the universal claims of Western feminism, and emphasizes how the specific material conditions, histories and struggles of 'Third World' women are often overlooked by Western feminism. For 
Spivak, this problem is most strikingly exemplified in Julia Kristeva's book About Chinese Women (1977).

Considering these explanations, it can be inferred that Third-world women are subjected to both the inferior and marginalized views of first world feminist, and patriarchy of their own society. This subjection to discrimination as a colonial subject on the one hand, and as woman on the other hand, causes their "double colonization". That means women in formerly colonized societies were doubly colonized by both imperial and patriarchal ideologies. The present study is written based on the conviction that E. M Forster's A Passage to India (1924) possesses the characteristics to be interpreted from the postcolonial feminism vantage point. In the following discussion, the elements of "double colonization" of Indian women have been elaborated in detail. However, it will be depicted that the female victim in this novel is not a third-world black woman as typically portrayed in novels with the same issues, but a white British woman who fails in her quest to see the real India.

\section{Discussion:}

EdwardMorgan Forster $(1879$ - 1970) was an English novelist, short story writer, essayist and librettist. He is best-known for his ironic and well-plotted novels examining class difference and hypocrisy in early 20th-century British society.A Passage to India (1924), his last and most controversial novel, brought him his greatest success his life. Throughout his life, Forster struggled to stand up to restrictions which English rationality imposed on individual liberty. Through his writing, he projected his personal ideas stressing that he was opposed to his country's crippling repression of non-Europeans.

Acclaimed as his masterpiece, A Passage to India is a picture of society in India under the British Raj, of the clash between East and West, and of the prejudiced misunderstandings that foredoomed goodwill. Criticized at first for its anti-British and possibly inaccurate bias, it has been praised as a superb character study of people of one race by a writer of another. However, as an Englishman, Forster is inevitably influenced by English social and cultural circumstances. In this dramatic story, Forster depicts, with sympathy and discernment, the complicated oriental reaction to British rule in India, and reveals the conflict of temperament and tradition involved in that relationship.

Published in 1924, this novel is the account of two British women, Adela Quested and Mrs. Moore, who question the standard behaviors of the English toward the 
Indians and suffer permanently from their unsettling experience in India. However, although the whole story evolves, around these two women, the emphasis is more on their failure than on their success. Brenda Silver, tendering a sympathetic feminist reading of A Passage to India, finds it to be "a study of what it means to be rapable, a social position that cuts across biological and racial lines to inscribe culturally constructed definitions of sexuality within a sex/gender/power system"(88).

Mrs. Moore is a good-hearted, religious, elderly woman with mystical leanings. The initial days of her visit to India are successful, as she connects with India and Indians on an intuitive level. But in the second part of the novel, she reaches to nihilism after visiting the cave. Her approach to the world has been in fact conditioned by the special mentality and sensibility of western civilization. However, unlike other English people in the story that want to impose their British categories on that nation, Mrs. Moore is more open to the world of the India. Therefore, in experiencing the echo in the cave, she lost all of her willingness, and life becomes meaningless for her. "Though provoking a little disappointment at first, the gradual disclosure of the character of Mrs. Moore unveils her venerable wisdom and receptive magnanimity" (Tayeb 44).

However, whereas Mrs. Moore's desire is bolstered by a genuine interest in and affection for Indians, Adela Quested appears to want to see the "real India", with her naïve passion, simply on intellectual grounds. She puts her mind to the task, but not her heart, and therefore never connects with Indians. After the excursion to Marabar Cave in the company of a young Indian doctor, Dr. Aziz, she returns alone and distressed. She accuses him of attempted assault, but later withdraws her accusation. Whatever happens or does not in the cave, it causes ruin to her "own kind", the imperial British. Forster depicts this British woman as a victim of a hallucination, or of a complex, unidentified intruder. Thus, although "They had no race-consciousn-ess-Mrs. Moor is too old, Miss. Quested too new-and they behaved to Aziz as to any young man who had been kind to them in the country"(142), they both fail after experiencing the crisis, to see real India.

Upon questioning whether the real crime is Adela's accusation or Aziz's assault, A Passage to India sets up an opposition between the English Woman and Indian man. Aziz's trial, and its run-up and aftermath, bring out all the racial tensions and prejudices between indigenous Indians and the British colonists who rule India. In chapter 24, an eminent barrister from Calcutta, directly announces rage to the presence of an Anglo-Indian in the platform. "we object to the presence of so many European ladies and gentlemen up on the platform... they will have the effect of 
intimidating our witnesses. Their place is with the rest of the public in the body of the hall" (223).

However, besides the story of these two British women, the double colonization of Indian women is also obvious in this novel. They are both victim of patriarchy and imperialism in their society. The focus of this article is on a postcolonial feminism vantage point concentrated around women, both Western and Indians, and the behavior and thought of native Indian men toward them.

LeelaGandi, in Postcolonial Theory:A critical introduction, believes that "the traumatic nationalist negotiation of the 'woman question' establishes a direct and problematic enmity between 'brown men' and 'white women' (97). She continues, " No one has understood or articulated this historical hostility more eloquently than E. M. Forster in his A Passage To India" (97). In the beginning of the novel, there is conversation between native Indian men about the arrogance of the occupying British and their insufferable treatment of even Indian intellectuals and professionals. They focused their conversation on women, and believe that "they are all the same"(35) they conclude that "all Englishwomen are haughty and venal"(36). This disdain is, of course, amply reciprocated, and as MrsCallendar, the wife of the local civil surgeon, observes: 'the best thing one can do to a native is to let him die' (48). Later, in chapter five, Forster depicts attitudes of the British interlopers, especially woman, toward native Indians. At the Bridge Party, which held to be a "bridge" between the two cultures, but result in heightened suspicion between West and East, the narcissism of western woman's view toward thirdworld women is depicted. Mrs. Turton, the novel's stereotype of the snobby, rude, and prejudiced English colonial wife, represents the attitude of most Englishwomen in India, explicitly regarding themselves superior to all Indians in seemingly every respect. Conversing with Miss. Quested, she said: "you are superior to them, anyway. Don't forget that, you are superior to everyone in India except one or two of the ranis, and they are on equality" (61). She viewed Indian women wearing a Purdah with inferiority, it is worth mentioning Partha Chatterjee's argument that the colonizers were able to "transform this figure of the Indian woman into a sign of the inherently oppressive and unfree nature of the entire cultural tradition of country"(118). They in fact allowed themselves to describe the experiences of 'Third World women' in the terms of western female subject constitution. Such an approach clearly ignores some very important differences in culture, history, language and social class.

The patriarchy is evident throughout the novel. The behavior and even the thought of Dr. Aziz toward his belated wife are accompanied by a sense of inferiority. He has no respect for his wife, and though he is Muslim, he easily shares the 
photograph of his wife to his Anglo-Indian friend, Mr. Fielding.While Mr.Fielding appreciates his Indian friend for sharingthe picture of his wife with him, Dr. Aziz said: "oh, it's nothing, she was not a highly educated woman or even beautiful, but put it away... she is of no importance, she is dead. I showed her to you because I have nothing else to show"(128-129). His speech reveals that although women are the focus of the men's conversation, they are effectively excluded, reduced to simply a medium of exchange between the men.

\section{Conclusion}

The attempt of Anglo-European nations to rule the world culturally, economically, and politically from a Eurocentric view with the opinion that this was good for everyone, was a central feature of modern imperialism. Feminism has critiqued post colonialism's narrow concept of power and domination. Otherwise, Feminism has itself been attacked by non-Western feminists for failing to examine its complicit role in imperialism and for theorizing a universal history of women from its own particular history. Postcolonial feminist want to demonstrate that Western feminism has been historically complicit in the project of imperialist expansion, and challenge the prevalent assumption that all women's lives and histories all around the world are the same.

In postcolonial feminism the emphasis is on the collusion of patriarchy and colonialism. The most significant collision of postcolonial theory and feminist theory occur around the figure of the Third-world woman, who suffers this "double colonization". However, post colonialists, as a critique of feminism, focused on its failure or inability to incorporate issues of race, or its propensity to stereotypes, or over-generalize the case of third world women, as eloquently depicted in Forster's A Passage to India.

"A Passage to India studies the viability of transcending the encumbrances of the colonial situation, on the part of both the colonialist and the native, in order to set up new formulas of social interaction and cross-cultural exchange" ( Tayeb 44). E. M. Forster skillfully brings up two important concerns of postcolonial feminism in his novel. The first one is the double-colonization of Indian women, which is masterfully shown through the interaction of English and Indian women on one hand, and the inferior looks of Indian men toward their women on the other.The second important issue is postcolonial feminist's critique on Western feminism. Many of them believe that a Third world woman has been shown as a "monolithic object" in texts of Western feminism (Suleri 760). However, Forster's satire is harsh on Englishw-omen, whom he depicts as overwhelmingly racist, selfrighteous, and viciously condescending to the native population. By depicting the 
limited worldview of the two British women in this novel, it can be concluded that the privilege attributed to them is the Western feminist prejudice and a onedimensional view.

\section{References and notes:}

1-Ashcroft, Bill, Gareth Griffiths, and Helen Tiffin. The Post-Colonial StudiesReader.New York:Routledge, 1995.

2-Bhabha, Homi K. The Locaion of Culture. London and New York: Routledge, 1994.

3-Bradshaw, David. The Cambridge Companion to E. M. Forster. New York: Cambridge University Press, 2007.

4 -Bressler, Charles E. Literary Criticism, An Introduction to Theory and Practice. New Jersey: Pesrson PrenticeHall, 2007.

5-Chatterjee, Pertha. The Possible India: Essays in Political criticism. Delhi: Oxford University Press, 1997.

6-Chew, Shirley. and David Richards. A Concise Companion to Postcolonial Literature. Oxford:Wiley-Blackwell, 2010.

7-Donaldson, Laura E. and Kwok Pui-lan. Postcolonialism, Feminism and Religious Discourse.London andNew York: Routledge, 2002.

8-Forster, E. M. A Passage to India. New York: Penguin Classics, 1986.

9-Gandhi, Leela. Postcolonial Theory:A critical introduction. Australia: Allen \& Unwin, 1998.

10-hooks, bell. Feminist Theory: From Margin to Center. Boston: south End Press, 1984.

11-Lawrence, Karen. Betsy Seifter, and Lois Ratner. The McGraw-Hill Guide to English Literature, vol2. United State of America: McGraw-Hill, Inc, 1985.

12-Lazarus, Neil. The Cambridge Companion to Postcolonial Literary Studies. New York: Cambridge University Press, 2006.

13-Mohanty, Chandra Talpade.'Under Western Eyes: Feminist scholarship and colonial Discourses', from The Post-Colonial StudiesReader. Bill Ashcroft, Gareth Griffiths, and Helen Tiffin. London and New York: Routledge, 1995.

14-Morton, Stephen. GayatriChakravortySpivak. London and New York: Routledge, 2003.

15-Silver, Brenda. 'Periphrasis, Power, and Rape in A Passage to India', Novel, 22 (1988), p.p.86-105.

16-Schwarz, Henry. AndSangeeta Ray. A Companion to Postcolonial Studies. Oxford:Blackwell, 2000.

17- Suleri, Sara. "Woman Skin Deep: Feminism and the Postcolonial Condition". Critical Inquiry, Vol. 18, No. 4, Identities (Summer, 1992), pp. 756-769

18-Tayeb, Lamia. "The Inscription of Cultural Bafflement in E. M. Forster's A Passage to India'". Interdisciplinary Literary Studies, Vol. 6, No. 1 (2004), pp. 37-59

Footnotes:

1. From "can subaltern speak?" in The Post-Colonial StudiesReader. Bill Ashcroft, Gareth Griffiths, and Helen Tiffin. London and New York: Routledge, 1995. 


\title{
Summary
}

\section{Postcolonial-Feminist elements in E. M. Forster's A Passage to India}

\author{
Sarah Tavassoli \\ Semnan University, Iran \\ NargesMirzapour \\ SemnanUniversity,İran
}

\begin{abstract}
Postcolonial feminism, also labeled third-world feminism, is an innovative approach, depicting the way women of colonized countries suffer from double colonization: native patriarchies and imperial ideology. While Western feminism focuses on gender discrimination, postcolonial feminism tries to broaden the analysis of the intersection of gender and multicultural identity formation. Postcolonial feminists believe that Western feminism is inattentive to the differences pertaining to class, race, feelings, and settings of women of colonized territories; therefore, postcolonial feminism warns the third-world woman not to copy nor imitate the Western woman's style, and tries to demonstrate what feminism means to woman in a non-western culture. The present article is based on the conviction that E. M Forster's A Passage to India (1924) possesses the characteristics to be interpreted from the postcolonial feminism vantage point. This novel is the account of two British women who question the standard behaviors of the English toward the Indians and suffer permanently from an unsettling experience in India. The female victim in this novel is not a third-world black woman as typically portrayed in such novels, but a white British woman who fails in her quest to see the real India. By depicting the limited worldview of the two British women this article concludes that the privilege attributed to them is indeed a one- dimensional view and Western feminist prejudice.
\end{abstract}

Keywords: Postcolonial feminism, A Passage to India, Double colonization, Patriarchy, Western feminism. 